\title{
Hydrogen Sulfide Regulates Homocysteine-Mediated Glomerulosclerosis
}

\author{
Utpal Sen Charu Munjal Natia Qipshidze Oluwasegun Abe Riyad Gargoum \\ Suresh C. Tyagi \\ Department of Physiology and Biophysics, University of Louisville School of Medicine, Louisville, Ky., USA
}

\section{Key Words}

Collagen $\cdot$ Matrix metalloproteinase $\cdot$ Inflammation •

Fibrosis · Hypertension $\cdot$ Renal dysfunction

\begin{abstract}
Background/Aims: In this study we tested the hypothesis that $\mathrm{H}_{2} \mathrm{~S}$ regulates collagen deposition, matrix metalloproteinases (MMP) and inflammatory molecules during hyperhomocysteinemia $(\mathrm{HHcy})$ resulting in attenuation of glomerulosclerosis and improved renal function. Materials and Methods: A genetic model of HHcy, cystathionine $\beta$-synthase heterozygous (CBS+/-) and wild-type (WT) 2-kidney (2K) mice were used in this study and supplemented with or without NaHS ( $30 \mu \mathrm{mol} / \mathrm{l}, \mathrm{H}_{2} \mathrm{~S}$ donor) in drinking water for 8 weeks. To expedite the renal damage associated with $\mathrm{HHcy}$, uninephrectomized (1K) mice of similar groups were also used. Results: Results demonstrated that $\mathrm{NAD}(\mathrm{P}) \mathrm{H}$ oxidase ( $\mathrm{p} 47^{\text {phox }}$ subunit) and blood pressure were upregulated in WT $1 \mathrm{~K}, \mathrm{CBS}+/-2 \mathrm{~K}$ and $\mathrm{CBS}+/-1 \mathrm{~K}$ mice with downregulation of $\mathrm{H}_{2} \mathrm{~S}$ production and reduced glomerular filtration rate. These changes were normalized with $\mathrm{H}_{2} \mathrm{~S}$ supplementation. Both pro- and active MMP- 2 and -9 and collagen protein expressions and glomerular depositions were also upregulated in WT $1 \mathrm{~K}, \mathrm{CBS}+/-2 \mathrm{~K}$ and $\mathrm{CBS}+/-1 \mathrm{~K}$ mice. Increased expressions of inflammatory molecules, intercellular cell adhesion
\end{abstract}

molecule- 1 and vascular cell adhesion molecule-1, as well as increased macrophage infiltration, were detected in WT $1 \mathrm{~K}$, $\mathrm{CBS}+/-2 \mathrm{~K}$ and $\mathrm{CBS}+/-1 \mathrm{~K}$ mice. These changes were ameliorated with $\mathrm{H}_{2} \mathrm{~S}$ supplementation. Conclusion: Together, these results suggest that increased oxidative stress and decreased $\mathrm{H}_{2} \mathrm{~S}$ in $\mathrm{HH} c y$ causes matrix remodeling and inflammation resulting in glomerulosclerosis and reduced renal function.

Copyright $\odot 2010$ S. Karger AG, Basel

\section{Introduction}

It is now well established that hyperhomocysteinemia (HHcy), an increased plasma homocysteine (Hcy) level, is a potent inducer of endothelial dysfunction, particularly in small vessels [1]. HHcy promotes atherosclerosis and thrombosis in susceptible animals, such as cystathionine $\beta$-synthase heterozygous (CBS+/-) mice fed with a high methionine diet [2]. The pathophysiological mechanisms of these effects, however, are less understood in the kidney, particularly in the process of glomerulosclerosis.

An increase in the Hcy level has been shown to induce oxidative stress through reactive oxygen species in the kidney $[3,4]$ and has been reported to induce local oxidative stress, mesangial expansion and podocyte dysfunc-

\section{KARGER}

(C) 2010 S. Karger AG, Basel

Fax +4161306 1234

E-Mail karger@karger.ch

www.karger.com
Accessible online at: www.karger.com/ajn
Utpal Sen

Department of Physiology and Biophysics

University of Louisville School of Medicine

500 South Preston Street, A-1214, Louisville, KY 40202 (USA)

Tel. +1 502852 3627, Fax +1 502852 6239, E-Mail u0sen001@ louisville.edu 
tion resulting in renal fibrosis [5]. In rat mesangial cell culture, Hcy promotes collagen accumulation and is associated with increased NAD $(\mathrm{P}) \mathrm{H}$ activity [5]. This suggests that Hcy induces local oxidative stress, cellular dysfunction and extracellular matrix metabolism in the glomerulus, all of which are associated with increased $\mathrm{NAD}(\mathrm{P}) \mathrm{H}$ activity.

The three enzymes CBS, cystathionine $\gamma$-lyase (CSE) and 3-mercaptopyruvate sulfurtransferase (3MST) metabolize Hcy to produce $\mathrm{H}_{2} \mathrm{~S}$ in the body [6-9]. The physiological function of endogenous $\mathrm{H}_{2} \mathrm{~S}$ is not clear and could be multifaceted; however, it is involved in the regulation of vascular tone [10] and protects neuronal cells from oxidative stress by increasing the intracellular concentration of antioxidant (glutathione) [11]. Increasing evidence suggests the potential antioxidant properties of $\mathrm{H}_{2} \mathrm{~S}$ in normal and pathophysiological conditions [1214]. In addition, recent reports have demonstrated that $\mathrm{H}_{2} \mathrm{~S}$ is a potential anti-inflammatory substance $[10,15$, 16]. However, the physiological role of $\mathrm{H}_{2} \mathrm{~S}$ in HHcy-associated renal remodeling is incompletely defined.

Matrix metalloproteinases (MMPs) degrade both the collagenous and noncollagenous components of the extracellular matrix, and are thereby actively involved in matrix turnover. Gelatinases, members of the family of MMPs, digest these products into smaller peptides. Among gelatinases, MMP-2 and MMP-9 have gained potential interest because of their capability to disrupt the kidney architecture [17-19]. Similarly, experimental evidence implicated sustained elevation of cell adhesion molecules, such as intercellular cell adhesion molecule-1 (ICAM-1) and vascular cell adhesion molecule-1 (VCAM1), in chronic inflammatory disorder, which leads to sclerosis [20]. HHcy has been reported to increase the expression of ICAM-1 [19] and VCAM-1 [19, 21] in experimental models by independent laboratories, including our own. In addition, macrophage infiltration in the kidney is one of the most important events for progression of nephropathy [22]. Despite these facts, however, the major contributing factors of HHcy-associated inflammation in the process of glomerulosclerosis still need to be defined comprehensively.

In this study we tested the hypothesis that HHcy-induced oxidative stress upregulates collagen deposition in the glomerulus leading to glomerulosclerosis through modulation of MMPs and inflammatory molecules. In addition, the regulatory role of $\mathrm{H}_{2} \mathrm{~S}$ to modulate this renal remodeling process was determined in an $\mathrm{HHcy}$ kidney.

Glomerular Remodeling and Hydrogen Sulfide

\section{Materials and Methods}

\section{Animals}

Wild-type (WT, C57BL/6J) and CBS+/- mice aged 8 weeks were obtained from Jackson Laboratories (Bar Harbor, Me., USA) and bred at the animal care facility at the University of Louisville. Genotypes of these mice were determined and 10-week-old male mice were used for this study. Mice were divided into 2 sets. The first set of mice had 2 normal kidneys $(2 \mathrm{~K})$ and were divided into the following groups: WT, CBS+/-, WT $+\mathrm{H}_{2} \mathrm{~S}[30 \mu \mathrm{mol} / \mathrm{l}$ for 8 weeks, NaHS (sodium hydrosulfide) was used as a donor of $\mathrm{H}_{2} \mathrm{~S}$ ] and $\mathrm{CBS}+/-+\mathrm{H}_{2} \mathrm{~S}$ ( $30 \mu \mathrm{mol} / \mathrm{l}$ for 8 weeks). The second set of mice were uninephrectomized $(1 \mathrm{~K})$ and separated as the 4 groups above. At the end of the experiments, mice were deeply anesthetized and sacrificed to harvest the tissues. All animal procedures were in accordance with the National Institute of Health Guidelines for Animal Research and were approved by the Institutional Animal Care and Use Committee of the University of Louisville School of Medicine.

\section{$\mathrm{H}_{2} \mathrm{~S}$ Treatment}

$\mathrm{H}_{2} \mathrm{~S}$ was supplemented to mice through drinking water in the form of NaHS, which in an aqueous solution produces an equal concentration of $\mathrm{H}_{2} \mathrm{~S}$. Typically, physiological ranges of $\mathrm{H}_{2} \mathrm{~S}$ vary from $10-100 \mu \mathrm{mol} / \mathrm{l}[12,23]$ and can rise as high as $160 \mu \mathrm{mol} / \mathrm{l}$ in the human plasma during septic shock [24]. To keep $\mathrm{H}_{2} \mathrm{~S}$ supplementation within the physiological range, we supplemented animals with $30 \mu \mathrm{mol} / \mathrm{l}$ of $\mathrm{H}_{2} \mathrm{~S}$. The density of $\mathrm{H}_{2} \mathrm{~S}$ is about $18 \%$ higher than the air; therefore, the evaporation rate of $\mathrm{H}_{2} \mathrm{~S}$ from the solutions is normally low. Moreover, the water bottle had a drinking tube with a small aperture, which minimized evaporation. In order to make sure animals took the appropriate amount of $\mathrm{H}_{2} \mathrm{~S}$ through drinking water, approximately every $12 \mathrm{~h}$ we changed the water with fresh $\mathrm{H}_{2} \mathrm{~S}$ in the appropriate groups. Within this period we observed a negligible amount of $\mathrm{H}_{2} \mathrm{~S}$ loss (approx. 2-3\%). Also, water consumption in treated versus nontreated groups was recorded, but no differences were found. No apparent toxicities of $\mathrm{H}_{2} \mathrm{~S}$ were noticed other than its effect on blood pressure (reported in 'Results').

\section{Cell Culture}

Mouse kidney mesangial cells were purchased from ATTC, and were cultured and maintained in T-25 flasks. The culture medium was DMEM/F-12 (50/50) containing 10\% fetal calf serum and antibiotics (Cellgro; Mediatech Inc., Herndon, Va., USA). Cells were trypsinized as described earlier [19] and plated onto 8 -well chamber slides. After experiments, the cells were processed for immunostaining and visualized under a laser scanning confocal microscope (FluoView 1000, Olympus) using an appropriate filter.

\section{Antibodies and Reagents}

Rat monoclonal antibody F4/80 was purchased from Abcam (Cambridge, Mass., USA). Anti-p47 ${ }^{\text {phox }}$, MMP-2 and -9, collagen IV, ICAM-1, VCAM-1 and HRP-linked secondary antibodies were from Santa Cruz Biotechnology (Santa Cruz, Calif., USA). Anti- $\beta$-actin antibody, NaHS and other analytical reagents were from Sigma-Aldrich (St. Louis, Mo., USA). Polyvinylidene difluoride membrane was from Bio-Rad (Hercules, Calif., USA). 


\section{Cryosectioning}

At the end of the experiments, kidneys were excised and cryopreserved in Peel-A-Way disposable plastic tissue embedding molds (Polysciences Inc., Warrington, Pa., USA) containing tissue freezing media (Triangle Biomedical Sciences, Durham, N.C., USA). These molds were kept frozen $\left(-70^{\circ} \mathrm{C}\right)$ until serial $5-\mu \mathrm{m}$ (for histological staining) or $2-\mu \mathrm{m}$ (for immunostaining) tissue sections were made in cryocut (Leica CM 1850). Cryosections were placed on Superfrost Plus microscope slides, air-dried and processed for staining.

\section{Western Blots}

The kidney cortical tissues were minced into fine particles with scissors and incubated with protein extraction buffer $(0.01$ $\mathrm{mol} / \mathrm{l}$ cacodylic acid $\mathrm{pH} 5.0,0.15 \mathrm{~mol} / \mathrm{l} \mathrm{NaCl}, 1 \mu \mathrm{mol} / 1 \mathrm{ZnCl}_{2}, 0.02$ $\mathrm{mol} / \mathrm{l} \mathrm{CaCl}_{2}, 0.0015 \mathrm{~mol} / \mathrm{l} \mathrm{NaN}_{3}$ and $0.01 \% \mathrm{v} / \mathrm{v}$ Triton X-100) overnight at $4^{\circ} \mathrm{C}$ with gentle agitation. The extracted protein was collected and $\mathrm{pH}$ rose to 7.4 by adding $1.5 \mathrm{~mol} / \mathrm{l}$ Tris ( $\mathrm{pH}$ 8.8.). An equal amount of protein was analyzed by $10 \%$ SDS-PAGE, transferred to a polyvinylidene difluoride membrane and probed with appropriate antibodies followed by reprobing with $\beta$-actin as described earlier [19].

\section{Immunostaining}

Cryosectioned $(2-\mu \mathrm{m})$ renal tissue samples and cells in the 8 -well chamber slides were washed with PBS ( $\mathrm{pH}$ 7.4) and blocked with $1 \%$ BSA for 15 min followed by 2 washes with PBS (5 min each). Slides were then fixed with $4 \%$ paraformaldehyde containing $0.25 \% \mathrm{~L}-\alpha$-lysophosphatidylcholine for $30 \mathrm{~min}$. After washing with PBS ( $3 \times, 5$ min each), samples were blocked with $1 \%$ BSA for $1 \mathrm{~h}$. Slides were then washed twice, primary antibody (p47phox, 1:100 dilutions in $1 \%$ BSA) was added, and incubated overnight at $4^{\circ} \mathrm{C}$ with gentle agitation. Excess antibody was washed with PBS $(3 \times, 5 \mathrm{~min}$ each) and secondary fluorescence-conjugated antibody (1:500 dilutions in 1\% BSA) was added and incubated for 2 h. Unbound secondary antibody was removed by PBS wash $(3 \times$, 5 min each), mounted on slides and visualized with fluorescence in a laser scanning confocal microscope (Olympus FluoView 1000) with an appropriate filter.

\section{Masson's Trichrome Staining}

Cryosectioned kidney tissue samples $(5-\mu \mathrm{m})$ were processed for Masson's trichrome (Richard-Allan Scientific, Kalamazoo, Mich., USA) staining according to the manufacturer's instructions for detecting collagen. Collagen appeared as a blue color.

\section{$R T-P C R$}

Total RNA was extracted from renal cortical tissue using Trizol Reagent (Gibco BRL) according to the manufacturer's instructions. The cDNA template was synthesized using a Promega kit. Primer sequences for mouse collagen IV were used as described elsewhere [25].

\section{Peroxidase-Based DAB Immunohistochemical Staining}

Kidney tissues were cryosectioned $(2-\mu \mathrm{m}$ thickness; Leica, CM 1850)and placed on slides, with the slides brought to room temperature before being washed with PBS ( $\mathrm{pH} 7.4,2 \times, 5$ min each). The sections were then blocked with $1 \%$ BSA (in PBS) for $15 \mathrm{~min}$, washed with PBS $(2 \times, 5 \mathrm{~min}$ each) and fixed with $4 \%$ paraformaldehyde containing $\mathrm{L}-\alpha$-lysophosphatidylcholine
$(0.25 \% \mathrm{w} / \mathrm{v})$ for $1 \mathrm{~h}$. Following fixation, sections were washed with PBS ( $3 \times, 5$ min each) and then blocked again with $1 \%$ BSA for $1 \mathrm{~h}$. The blocking solution was discarded and the slides were washed with PBS $(2 \times, 5$ min each) followed by incubation with primary antibody $(1: 100$ in $1 \% \mathrm{BSA})$ overnight at $4^{\circ} \mathrm{C}$. Slides were washed with PBS $(3 \times, 5$ min each) to remove excess antibody, followed by incubation with HRP-conjugated secondary antibody (1:250 in 1\% BSA) for $2 \mathrm{~h}$ at room temperature. Slides were then washed with PBS $(3 \times, 5$ min each) and DAB substrate-chromogen was applied, incubated at $37^{\circ} \mathrm{C}$ for $30 \mathrm{~min}$, rinsed with distilled water and mounted in mounting medium. DAB staining was visualized under a microscope with dark brown end-product at the site of the target antigen.

\section{Measurement of Glomerular Filtration Rate}

Alzet Mini-Osmotic Pumps (Durect Corp., Cupertino, Calif., USA) with a constant flow rate $(8 \mu \mathrm{l} / \mathrm{h})$ filled with $200 \mu \mathrm{l}$ of $5 \%$ FITC-inulin (dialyzed) were inserted into the peritoneal cavity through a small midline incision under light anesthesia. Animals were then placed in metabolic cages. Both collected plasma and urine samples were buffered at $\mathrm{pH} 7.4$ with $500 \mathrm{mmol} / \mathrm{l} \mathrm{HEPES}$ before taking the FITC fluorescence value to minimize the effect of $\mathrm{pH}$ [26]. The titrated $50-\mu \mathrm{l}$ samples were then loaded onto each well of a 96-well plate. Fluorescence was determined using Spectra Max (Molecular Device, Sunnyvale, Calif., USA) with 485-nm excitation and read at 538-nm emission. Glomerular filtration rate (GFR) was calculated based on inulin clearance using the 24hour urinary FITC-inulin excretion rate (urinary fluorescence counts/24 h) divided by the concentration of plasma FITC-inulin (fluorescence counts/ $\mu \mathrm{l}$ ).

\section{Statistical Analysis}

Values are given as means \pm SEM from ' $n$ ' numbers of animals in each group as mentioned in each of the figure legends. The difference between mean values of multiple groups were analyzed by one-way analysis of variance (ANOVA) followed by Scheffe's post hoc analysis. Comparisons between groups were made with the use of Student's independent t test. Significance was accepted at $\mathrm{p}<0.05$.

\section{Results}

\section{Endogenous Production of Tissue $\mathrm{H}_{2} \mathrm{~S}$ and CSE \\ Expression Was Attenuated in HHcy Mice}

$\mathrm{CBS}+/-$ mice are hyperhomocysteinemic, and previously we reported that $1 \mathrm{~K} \mathrm{CBS}+/-$ mice further developed HHcy [18]. Also, 1K WT exhibited a moderate increase in plasma Hcy compared to their $2 \mathrm{~K}$ littermates [18]. Here, we sought to determine whether the increased plasma level of Hcy had any causative effect on endogenous production of $\mathrm{H}_{2} \mathrm{~S}$ in the renal cortical tissue. Our results showed that $\mathrm{H}_{2} \mathrm{~S}$ production was marginally low in $1 \mathrm{~K}$ WT and was further downregulated in $2 \mathrm{~K} \mathrm{CBS+/-}$ mice compared to $2 \mathrm{~K}$ WT mice (fig. 1a). However, in $1 \mathrm{~K}$ $\mathrm{CBS}+/-$ mice, $\mathrm{H}_{2} \mathrm{~S}$ production was significantly attenu- 


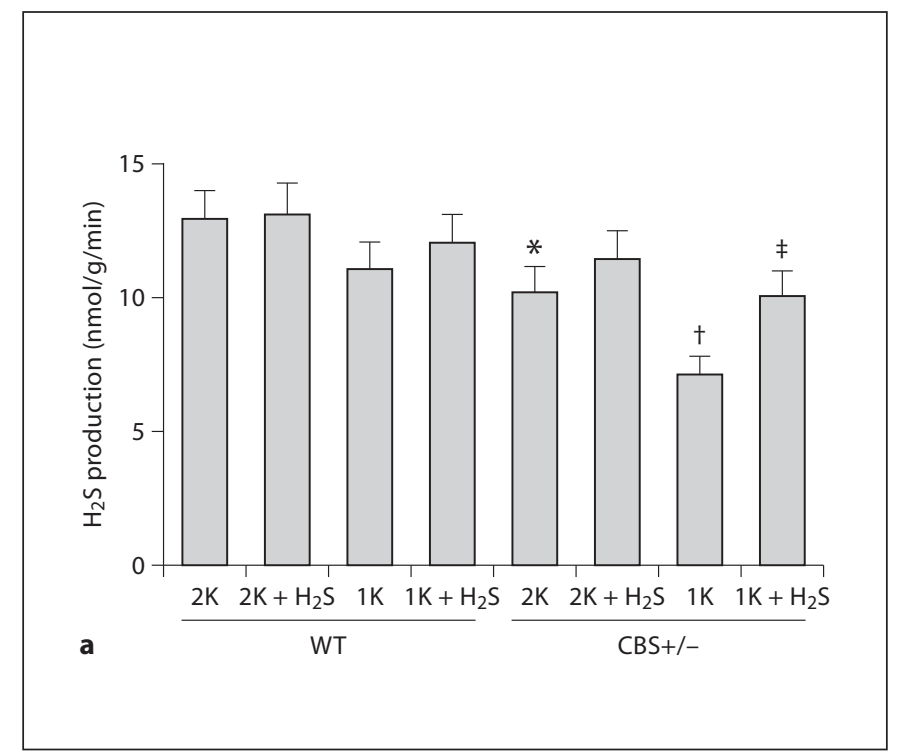

Fig. 1. Attenuated renal cortical tissue $\mathrm{H}_{2} \mathrm{~S}$ production and CSE expressions were normalized by $\mathrm{H}_{2} \mathrm{~S}$ treatment. a In the presence of $10 \mathrm{mmol} / \mathrm{l} \mathrm{L}$-cysteine and $2 \mathrm{mmol} / \mathrm{l}$ pyridoxol 5 '-phosphate, $\mathrm{H}_{2} \mathrm{~S}$ production in the kidney cortex tissue homogenates was measured following the procedure as described in the 'Materials and Methods'. * $\mathrm{p}<0.01$ vs. $2 \mathrm{~K} \mathrm{WT;}{ }^{\dagger} \mathrm{p}<0.05$ vs. $2 \mathrm{~K} \mathrm{CBS}+/-$;

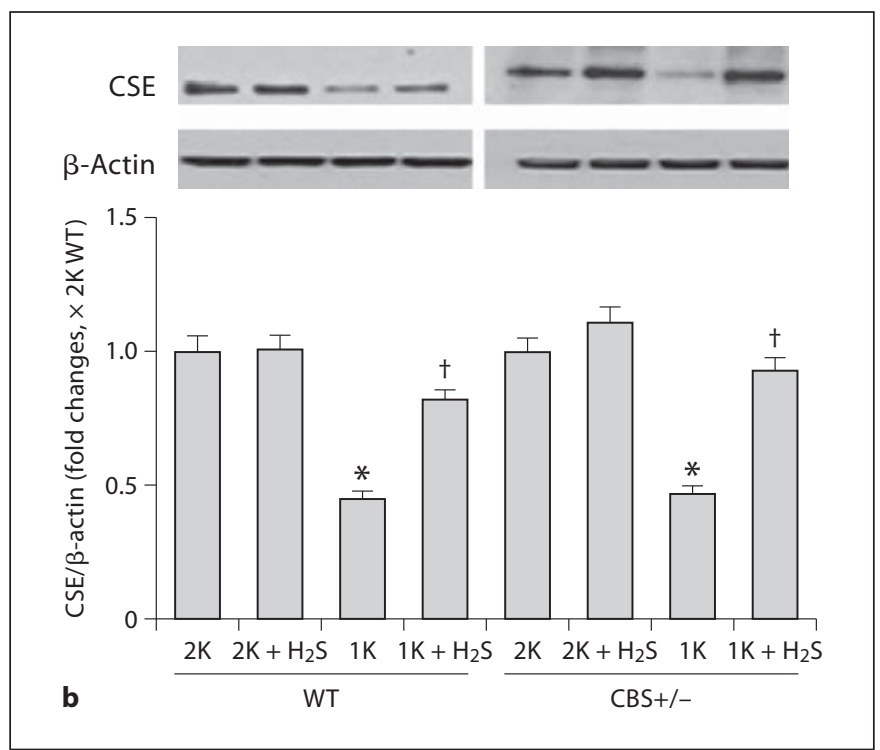

${ }^{\ddagger} \mathrm{p}<0.05$ vs. $1 \mathrm{~K} \mathrm{CBS}+/-$. b Representative Western blot showed CSE expression in the kidney cortex tissue in different experimental animal groups. The bar diagram showed densitometric analyses of CSE expression against $\beta$-actin loading control. Data represents the mean $\pm \mathrm{SEM}, \mathrm{n}=4-7 .{ }^{*} \mathrm{p}<0.01$ vs. respective $2 \mathrm{~K}$ mice and ${ }^{\dagger} \mathrm{p}<0.01$ vs. respective $1 \mathrm{~K}$ mice. ated compared to both $2 \mathrm{~K}$ littermates and $2 \mathrm{~K}$ WT mice. Interestingly, supplementation of $\mathrm{H}_{2} \mathrm{~S}(30 \mu \mathrm{mol} / \mathrm{l}) \mathrm{im}$ proved endogenous generation of $\mathrm{H}_{2} \mathrm{~S}$ in these animal groups (fig. 1a). These results clearly suggest that HHcy attenuates endogenous $\mathrm{H}_{2} \mathrm{~S}$ production and that $\mathrm{H}_{2} \mathrm{~S}$ supplementation normalizes $\mathrm{H}_{2} \mathrm{~S}$ production.

CSE is one of the enzymes involved in the metabolism of $\mathrm{Hcy}$ and production of $\mathrm{H}_{2} \mathrm{~S}$. In order to assess whether $\mathrm{HHcy}$ has any modulatory role in the expression of CSE, we measured renal cortical CSE expression by Western blot. Our results showed that CSE expression was downregulated in $1 \mathrm{~K}$ WT and $1 \mathrm{~K} \mathrm{CBS}+/-$ mice (fig. 1b). However, supplementation of $\mathrm{H}_{2} \mathrm{~S}$ ameliorated CSE expression, suggesting that $\mathrm{H}_{2} \mathrm{~S}$ plays a role in CSE expression during HHcy.

\section{$\mathrm{H}_{2} \mathrm{~S}$ Reduced Increased Blood Pressure in $\mathrm{CBS}+/-$ Mice}

We used a $1 \mathrm{~K}$ model to expedite the glomerular damage; however, the $1 \mathrm{~K}$ animal often develops hypertension and, consequently, renal damage. In order to assess the degree of hypertension and the role of $\mathrm{H}_{2} \mathrm{~S}$ treatment in regulating blood pressure, we measured blood pressure; the summarized data is shown in figure $2.1 \mathrm{~K} \mathrm{WT}$ ani- mals developed a small increase of blood pressure compared to $2 \mathrm{~K} \mathrm{WT}$, which was not significant. There was, however, a significant increase of blood pressure in $2 \mathrm{~K}$ $\mathrm{CBS}+/-$ mice compared to $2 \mathrm{~K}$ WT animals. $1 \mathrm{~K} \mathrm{CBS+/-}$ mice showed a further increase of blood pressure (6 to 7 $\mathrm{mm} \mathrm{Hg}$ ), but this was not significant compared to $2 \mathrm{~K}$ $\mathrm{CBS}+/-$ animals. Interestingly, $\mathrm{H}_{2} \mathrm{~S}$ supplementation normalized this increase of blood pressure in $1 \mathrm{~K} \mathrm{WT}$ and $2 \mathrm{~K}$ and $1 \mathrm{~K} \mathrm{CBS}+/-$ mice. The heart rate, however, did not change between groups with or without $\mathrm{H}_{2} \mathrm{~S}$ supplementation (data not shown). These results specifically suggest that $\mathrm{H}_{2} \mathrm{~S}$ acts at least through two different mechanisms: (1) through reducing blood pressure, which has immense impact on glomerular damage; and (2) through its antioxidant properties, which reduces oxidative damages induced by HHcy.

\section{$\mathrm{H}_{2} \mathrm{~S}$ Supplementation Improved GFR}

To assess the impact of HHcy on renal function and any regulatory role of $\mathrm{H}_{2} \mathrm{~S}$ on it, GFR was measured using the gold standard method (FITC-inulin clearance) as described in 'Materials and Methods'. 2K CBS+/- mice showed a marginally low GFR compared to their agematched 2K WT littermates (fig. 3). Although GFR in 1K 


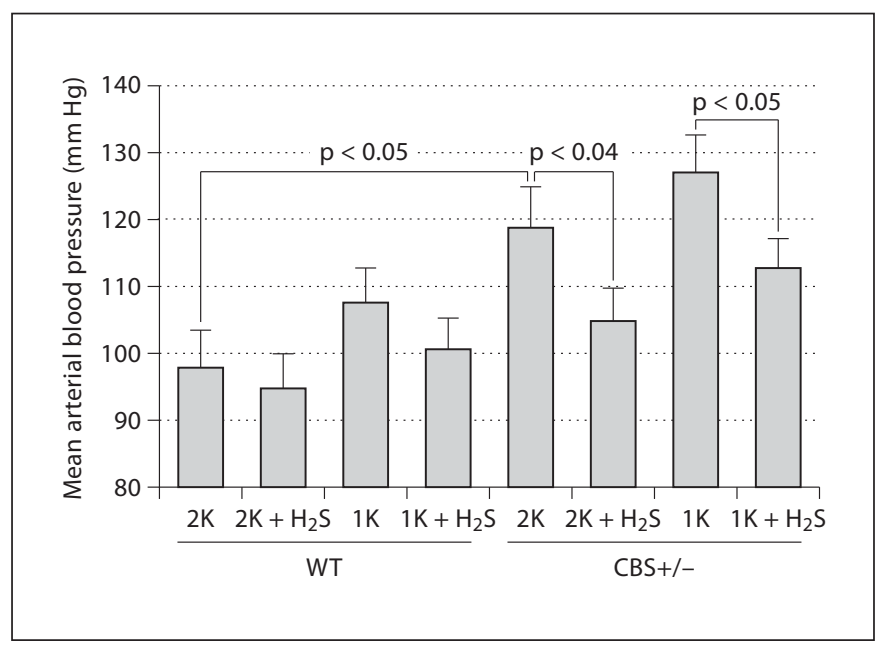

Fig. 2. Increased blood pressure was normalized with $\mathrm{H}_{2} \mathrm{~S}$ supplementation. Blood pressure was measured using radiotelemetry devices (model TA11PA-C10; DSI, St. Paul, Minn., USA). A miniature intra-arterial catheter was surgically implanted in the ventral subcutaneous space with the catheter inserted into the left carotid artery. Mice were allowed to recover for 1 week before they were placed on telemetric matrix while they remained in their cages, and devices were turned on for hemodynamics measurement. Summarized data ( $\mathrm{n}=4-6$ mice/group).

WT mice was low, it was not significant compared to $2 \mathrm{~K}$ WT mice. However, GFR of $1 \mathrm{~K} \mathrm{CBS+/-} \mathrm{mice} \mathrm{was} \mathrm{sig-}$ nificantly lower compared to $2 \mathrm{~K} \mathrm{CBS}+/-$ littermates. Interestingly, exogenous supplementation of $\mathrm{H}_{2} \mathrm{~S}$ dramatically improved GFR in $1 \mathrm{~K} \mathrm{CBS+/-} \mathrm{mice} \mathrm{(fig.} 3$ ), suggesting the beneficial effect of $\mathrm{H}_{2} \mathrm{~S}$ on Hcy-induced kidney function.

\section{Expression of the $N A D(P) H$ Oxidase $p 47^{\text {phox }}$ Subunit in the Renal Cortical Tissue}

Previously, we reported that plasma Hcy increased with a declining trend of plasma $\mathrm{H}_{2} \mathrm{~S}$ level, followed by an increase of renal injury in $\mathrm{CBS}+/-$ mice, especially in $1 \mathrm{~K}$ animals [18]. This was evidenced with an increase in superoxide $\left(\mathrm{O}_{\overline{2}}^{\overline{ }}\right)$ production, urinary protein loss and apoptotic cell death in the glomerulus. Here we determined the $\mathrm{NAD}(\mathrm{P}) \mathrm{H}$ oxidase $\mathrm{p} 47^{\text {phox }}$ subunit in the different experimental groups used in this study because it is involved in the oxidative redox signal. Also, to explore whether or not $\mathrm{H}_{2} \mathrm{~S}$ has a regulatory role on this molecule, we examined its expression in the cortical tissue extract following $\mathrm{H}_{2} \mathrm{~S}$ supplementation. A representative blot showed increased $\mathrm{p} 47^{\text {phox }}$ expressions in the renal cortical tissue extract of $1 \mathrm{~K} \mathrm{WT}, 2 \mathrm{~K} \mathrm{CBS}+/-$ and $1 \mathrm{~K} \mathrm{CBS}+/-$ mice

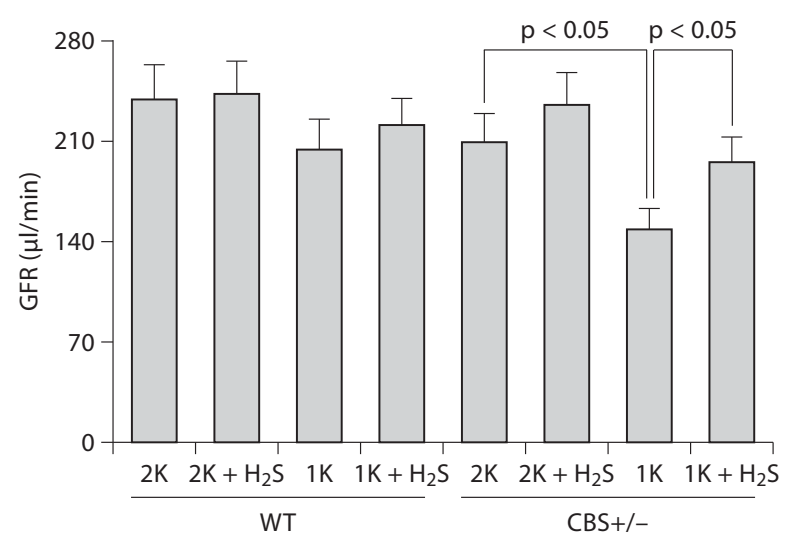

Fig. 3. Impaired GFR in HHcy mice was ameliorated by $\mathrm{H}_{2} \mathrm{~S}$ supplementation. $\mathrm{NaHS}\left(\mathrm{H}_{2} \mathrm{~S}\right.$ donor, $\left.30 \mu \mathrm{mol} / \mathrm{l}\right)$ was supplemented with drinking water for 8 weeks in the appropriate groups as shown. GFR was measured using the gold standard method (FITC-inulin) as described in 'Materials and Methods'. Data represents the mean \pm SEM, $n=7$ in each group.

compared to $2 \mathrm{~K}$ WT animals (fig. 4). These increased expressions of $\mathrm{p} 47^{\text {phox }}$ were almost completely abolished in a separate group of $1 \mathrm{~K}$ WT mice, and significantly diminished in $2 \mathrm{~K} \mathrm{CBS}+/-$ and $1 \mathrm{~K} \mathrm{CBS}+/-$ mice supplemented with $\mathrm{H}_{2} \mathrm{~S}$ (NaHS, $30 \mu \mathrm{mol} / \mathrm{l}$; fig. 4). Thus, these results suggest that high $\mathrm{Hcy}$ induces the $\mathrm{NAD}(\mathrm{P}) \mathrm{H}$ oxidase $\mathrm{p} 47^{\text {hox }}$ subunit, causing oxidative stress. This oxidative stress induced by Hcy plays a pivotal role in glomerular injury and $\mathrm{H}_{2} \mathrm{~S}$ triggers this mechanism, partly through its antioxidant properties.

\section{In vitro $\mathrm{H}_{2} \mathrm{~S}$ Attenuated Hcy-Induced p47phox \\ Upregulation}

To determine the biological impact of $\mathrm{H}_{2} \mathrm{~S}$ in HHcyassociated $\mathrm{p} 47^{\text {phox }}$ expression, both in vitro and in vivo experiments were performed using kidney mesangial cells and renal tissue sections. Figure 5a shows that in in vitro cell culture, Hcy induced upregulation of $\mathrm{p} 47^{\text {phox }}$. When cells were pretreated and incubated with $\mathrm{H}_{2} \mathrm{~S}$ along with Hcy, this upregulation was ameliorated. Figure 5b shows the expression of $\mathrm{p} 47^{\text {phox }}$ in the glomerulus. The fluorescence intensity was higher in $1 \mathrm{~K} W \mathrm{WT}$ and $2 \mathrm{~K}$ CBS+/- mice compared to $2 \mathrm{~K}$ WT littermates. However, this intensity was robustly increased in $1 \mathrm{~K} \mathrm{CBS+/-glom-}$ 


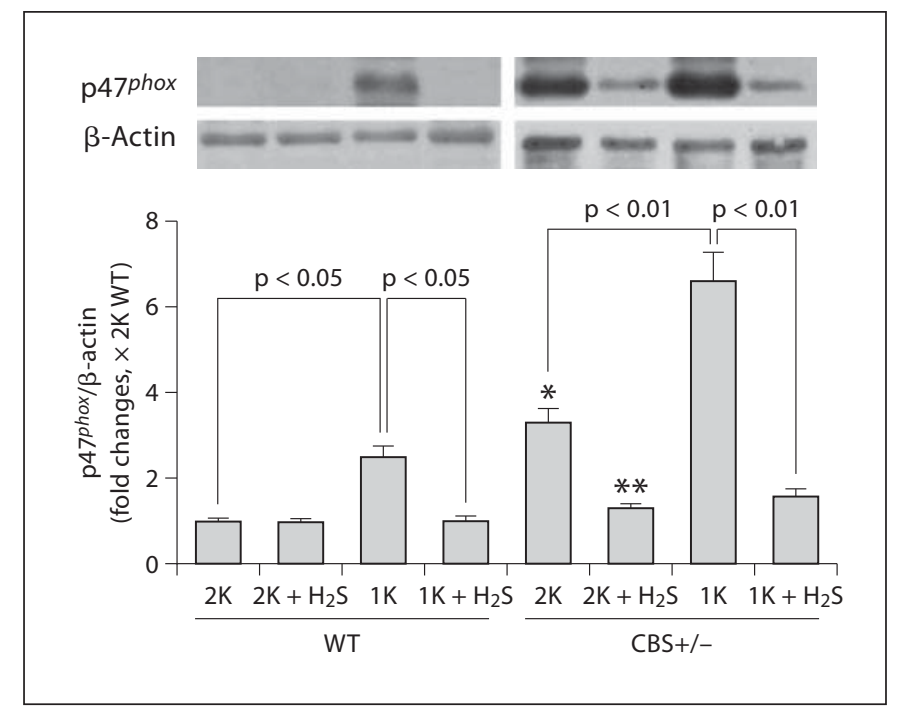

Fig. 4. $\mathrm{H}_{2} \mathrm{~S}$ mitigated $\mathrm{NAD}(\mathrm{P}) \mathrm{H}$ oxidase ( $47^{\text {phox }}$ subunit) in the HHcy kidney. Western blot was performed to measure the $47^{\text {phox }}$ subunit of $\mathrm{NAD}(\mathrm{P}) \mathrm{H}$ oxidase in the kidney cortex tissue extract using anti-p47phox antibody. Data represents the mean \pm SEM, $\mathrm{n}=5-7$. * Significant difference $(\mathrm{p}<0.05)$ compared to $2 \mathrm{~K} \mathrm{WT}$, and ${ }^{* *}$ significant difference $(\mathrm{p}<0.05)$ compared to $2 \mathrm{~K} \mathrm{CBS}+/-$.

erulus, indicating higher expression of $\mathrm{p} 47^{\text {phox }}$ compared to other nontreated groups. When a similar group of mice was treated with $\mathrm{H}_{2} \mathrm{~S}$, this induction of $\mathrm{p} 47^{\text {phox }}$ was attenuated (fig. 5b). Together, these results suggest that Hcy induces $\mathrm{p} 47^{\text {phox }}$ and $\mathrm{H}_{2} \mathrm{~S}$ downregulates $\mathrm{p} 47^{\text {phox }}$ during HHcy.

\section{Induction of MMP-2 and -9 in the Renal Cortex}

Oxidative stress regulates MMPs, which play a role in collagen remodeling in the matrix during HHcy [18, 27, 28]. Therefore, we measured the expressions of MMP-2 and -9 in the renal cortex tissue-extracted protein by Western blot. Summarized data in figure 6 showed that both pro- and active forms of MMP-9 were increased significantly in $1 \mathrm{~K} \mathrm{WT}, 2 \mathrm{~K} \mathrm{CBS}+/-$ and $1 \mathrm{~K} \mathrm{CBS}+/-$ mice. Interestingly, $\mathrm{H}_{2} \mathrm{~S}$ inhibited expression of both these forms in the cortex. The expression of the active form of MMP-2 was higher in $1 \mathrm{~K} \mathrm{WT}$ animals compared to $2 \mathrm{~K}$ WT, whereas both pro- and active forms of this proteinase were found upregulated in $2 \mathrm{~K}$ and $1 \mathrm{~K} \mathrm{CBS}+/-$ animals (fig. 6). Like MMP-9, upregulation of MMP-2 was also attenuated, at least in $1 \mathrm{~K} \mathrm{WT}$ and $1 \mathrm{~K} \mathrm{CBS+/-} \mathrm{mice,}$ with the supplementation of $\mathrm{H}_{2} \mathrm{~S}$ (fig. 6). These results suggest that $\mathrm{H}_{2} \mathrm{~S}$ plays a role in mitigating MMP-2 and -9 inductions during HHcy.

\section{Exogenous $\mathrm{H}_{2} \mathrm{~S}$ Modulated Collagen Remodeling in} the Glomerulus

Collagen is one of the major components of extracellular matrix, and excessive collagen accumulation is related to the pathophysiology of tissue remodeling. Here, we sought to determine collagen deposition in the glomerulus of WT and CBS+/- mice in different experimental groups. The results, as shown in figure 7 , suggest that exogenous $\mathrm{H}_{2} \mathrm{~S}$ ameliorates Hcy-induced collagen deposition in the glomerulus.

Collagen IV is a structural component of glomerular basal lamina, and excessive accumulation of collagen IV in the lamina adversely affects glomerular function. Therefore, we measured collagen IV expression in the renal cortical tissue-extracted protein. In accordance with histological collagen distribution in the kidney tissues, Western blot analyses of cortical tissues demonstrated that, although $2 \mathrm{~K} \mathrm{CBS}+/-$ mice had higher amounts of collagen IV expression compared to $2 \mathrm{~K} \mathrm{WT}$, the presence of collagen protein in $1 \mathrm{~K} \mathrm{CBS+/-} \mathrm{was} \mathrm{much} \mathrm{higher} \mathrm{than}$ in $1 \mathrm{~K} \mathrm{WT}$ and $2 \mathrm{~K} \mathrm{CBS+/-} \mathrm{mice} \mathrm{(fig.} \mathrm{8).} \mathrm{H}_{2} \mathrm{~S}$, however, normalized this protein expression in the renal cortical tissue (fig. 8). Previously, we reported increased renal injury in $1 \mathrm{~K} \mathrm{CBS+/-} \mathrm{mice} \mathrm{as} \mathrm{a} \mathrm{result} \mathrm{of} \mathrm{elevated} \mathrm{plasma} \mathrm{Hcy}$ level and Hcy-induced oxidative stress [18]. The present results confirm that this injury leads to excessive accumulation of collagen leading to glomeruloslerosis. $\mathrm{H}_{2} \mathrm{~S}$, however, ameliorates collagen expression, probably through its anti-oxidant properties.

Additionally, the collagen IV gene expression level was measured and normalized with internal control GAPDH (fig. 9). This suggests that expression of protein level was due to transcriptional regulation of the collagen IV gene.

\section{$\mathrm{H}_{2} \mathrm{~S}$ Acted as an Anti-Inflammatory Substance}

Inflammation causes upregulation of inflammatory molecules, such as ICAM-1 and VCAM-1, leading to inflammatory disorder and sclerosis. Therefore, we measured these molecules in our next experiment. As shown in the representative figure (fig. 10), increased expressions of the inflammatory molecules ICAM-1 and VCAM-1 were observed in $1 \mathrm{~K} \mathrm{WT}$ as well as in $2 \mathrm{~K}$ and $1 \mathrm{~K} \mathrm{CBS+/-} \mathrm{mice,} \mathrm{and} \mathrm{were} \mathrm{significantly} \mathrm{higher} \mathrm{com-}$ pared to $2 \mathrm{~K}$ WT control animals. We reported earlier that these mice were hyperhomocysteinemic with low plasma $\mathrm{H}_{2} \mathrm{~S}$ levels [18]. Interestingly, exogenous supplementation of $\mathrm{H}_{2} \mathrm{~S}$ in the similar groups of animals attenuated these adhesion molecule expressions (fig. 10). These results indicate that Hcy induces the inflamma- 
Fig. 5. $\mathrm{H}_{2} \mathrm{~S}$ diminished Hcy-induced $4^{77^{\text {hox }}}$ upregulation in mesangial cells as well as in the glomerulus. a Kidney mesangial cells were cultured in 8-well chamber slides. Cells were pretreated with $\mathrm{H}_{2} \mathrm{~S}$ (NaHS, $30 \mu \mathrm{mol} / \mathrm{l}$ ) $15 \mathrm{~min}$ before cells were exposed to Hcy $(50 \mu \mathrm{mol} / \mathrm{l})$ for $48 \mathrm{~h}$ (NaHS and Hcy were freshly added after every $12 \mathrm{~h}$ ). Cells were fixed, permeabilized, blocked with $1 \%$ BSA in PBS, and immunostained with anti-p47phox antibody secondarily conjugated with FITC. Also, cells were counterstained with DAPI. Fluorescence images were taken under the laser scanning confocal microscope (FluoView 1000 , Olympus). Green fluorescence, as indicated by arrows, indicated $\mathrm{p} 47^{\text {phox }}$ expression. Representative images from independent experiments $(\mathrm{n}=5)$. b Representative images of $\mathrm{p} 47^{\text {phox }} \mathrm{immu}$ nostained glomerulus ( $\mathrm{n}=5-7$ animals/group) from different experimental animal groups.
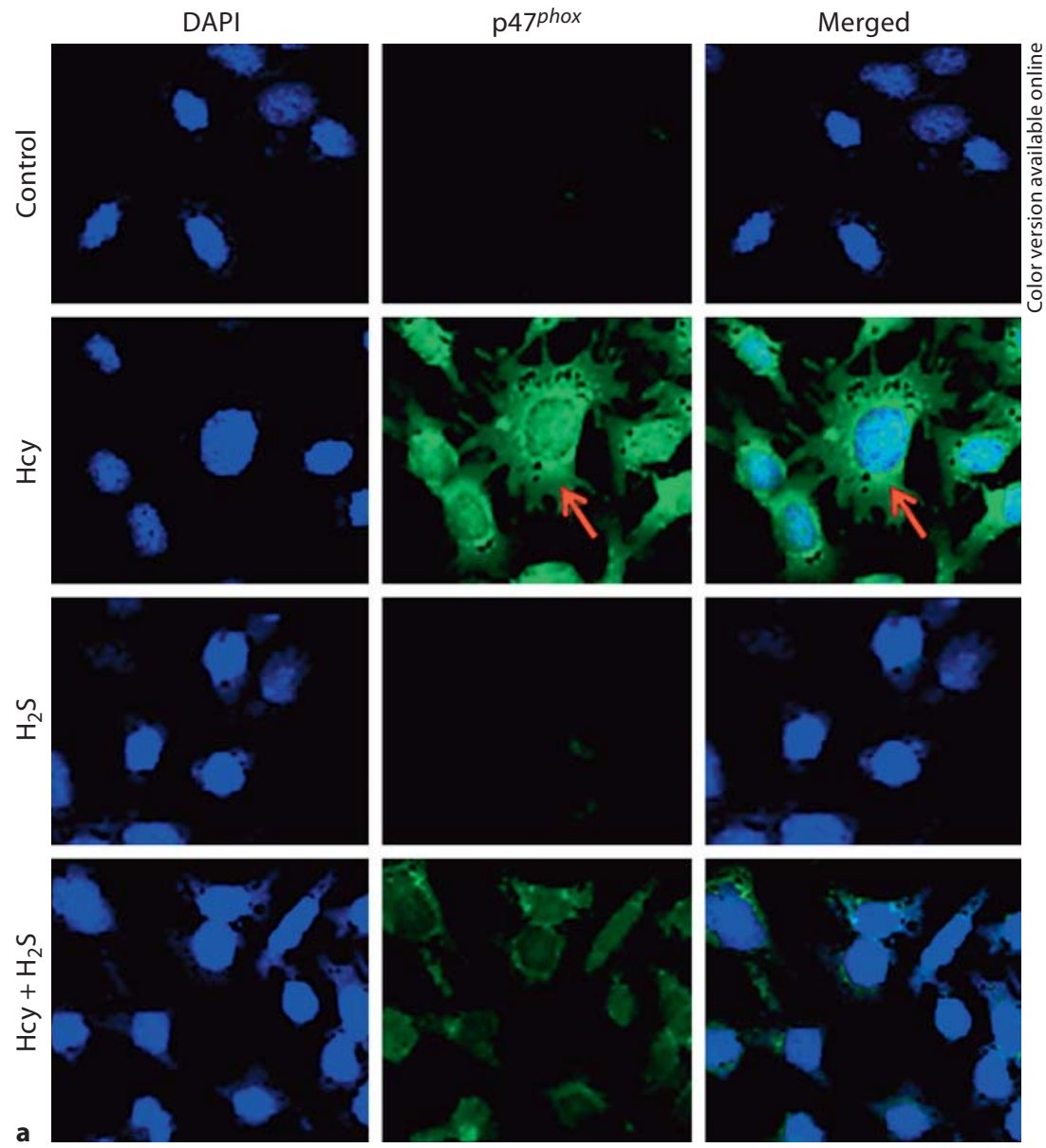

$2 \mathrm{~K}$

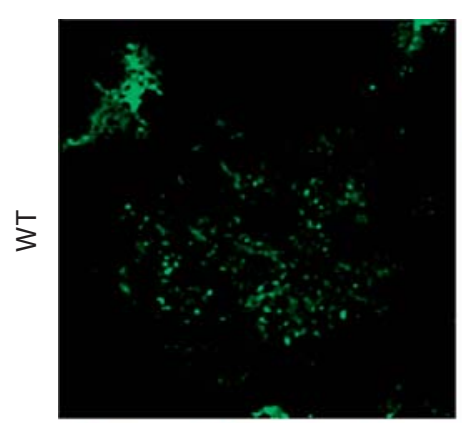

$2 \mathrm{~K}+\mathrm{H}_{2} \mathrm{~S}$

$1 \mathrm{~K}$
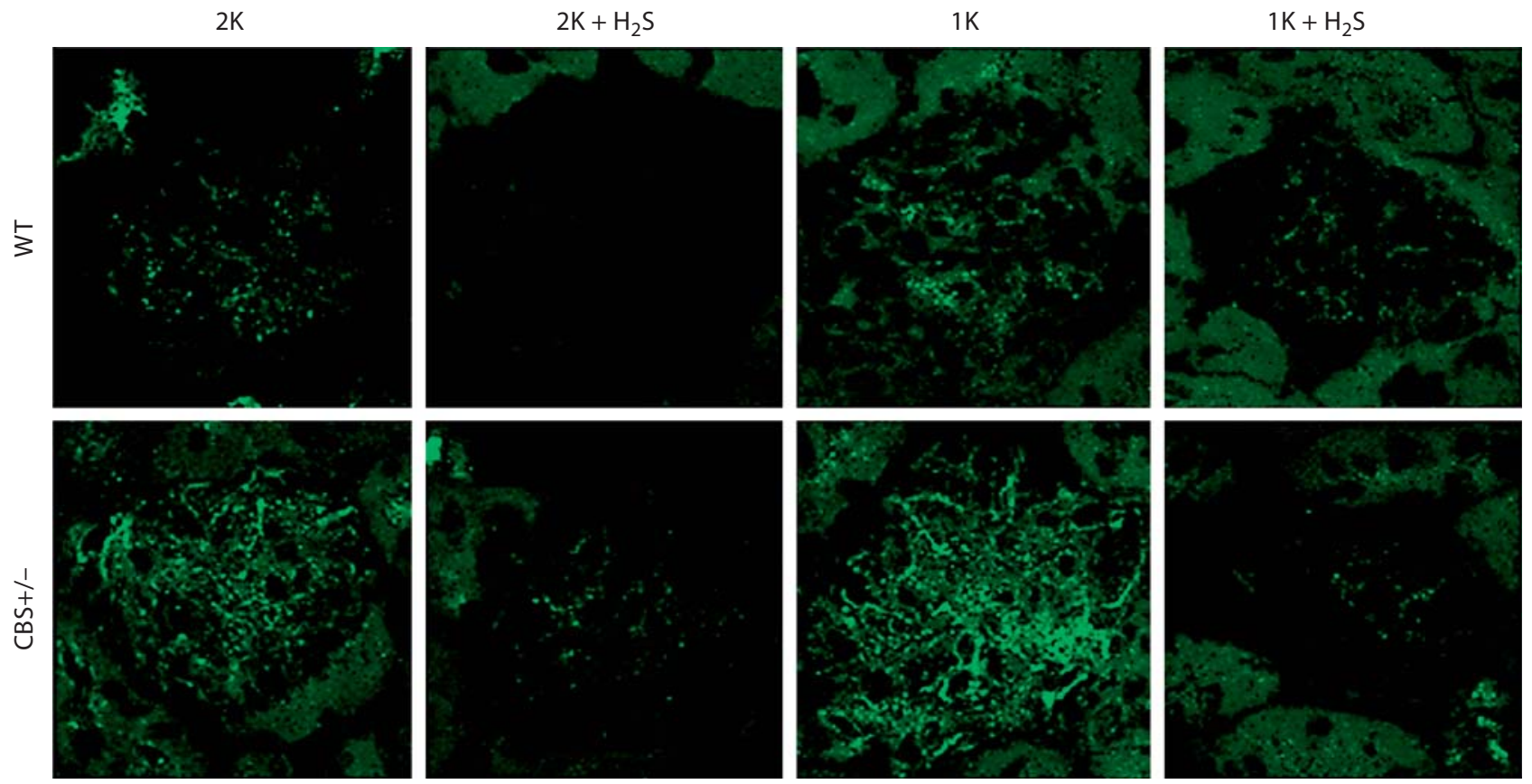

$2 \mathrm{~K}+\mathrm{H}_{2} \mathrm{~S}$

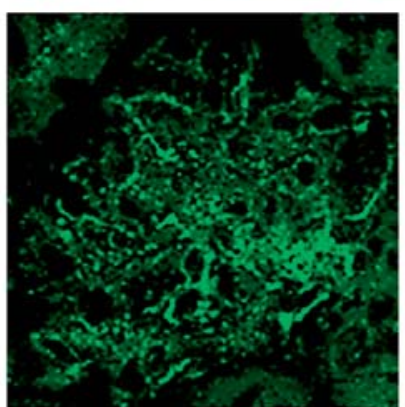

$1 \mathrm{~K}$

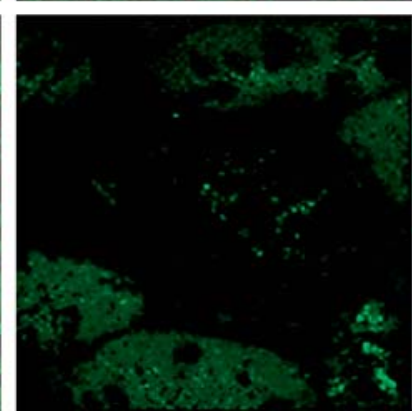

$1 \mathrm{~K}+\mathrm{H}_{2} \mathrm{~S}$ 
tory molecules ICAM-1 and VCAM-1 in the renal cortex, and $\mathrm{H}_{2} \mathrm{~S}$ acts as an anti-inflammatory substance which downregulates these molecules in Hcy-induced renal cortex.

\section{$\mathrm{H}_{2} \mathrm{~S}$ Supplementation Inhibited Macrophage Infiltration}

Macrophage infiltration and accumulation in the kidney is one of the most important events for the progression of glomerulosclerosis [22]. In our next experiment, we determined macrophage infiltration in the glomerulus. To do this, we immunostained kidney sections $(2-\mu \mathrm{m}$ thickness) with murine F4/80 antibody, one of the markers of macrophages. As shown in the representative images (fig. 11), increased expression of F4/80 antigen was observed in the glomerulus of $1 \mathrm{~K} \mathrm{WT}$ and both $2 \mathrm{~K}$ and $1 \mathrm{~K} \mathrm{CBS+/-} \mathrm{mice} \mathrm{compared} \mathrm{to} 2 \mathrm{~K}$ WT control animals. The abundance of F4/80 antigen expression in the glomerulus was attenuated with $\mathrm{H}_{2} \mathrm{~S}$ supplementation in similar groups of animals (fig. 11). These results indicate that increased plasma Hcy and a subsequent decrease in plasma $\mathrm{H}_{2} \mathrm{~S}$ level induces macrophage infiltration in the glomerulus, whereas supplementation of $\mathrm{H}_{2} \mathrm{~S}$ limits this infiltration associated with $\mathrm{HHcy}$, thus preventing glomerulosclerosis.

\section{Discussion}

We previously reported that the decreased plasma level of $\mathrm{H}_{2} \mathrm{~S}$ in WT $1 \mathrm{~K}, \mathrm{CBS}+/-2 \mathrm{~K}$ and $\mathrm{CBS}+/-1 \mathrm{~K}$ animals was strongly associated with increased plasma Hcy and that supplementation of $\mathrm{H}_{2} \mathrm{~S}$ ameliorated $\mathrm{HHcy}$-associated chronic renal failure [18]. Results from the present study demonstrated that abilities of renal cortical tissue to generate endogenous $\mathrm{H}_{2} \mathrm{~S}$ were impaired in $1 \mathrm{~K}$ WT mice with further disabilities in both $2 \mathrm{~K}$ and $1 \mathrm{~K} \mathrm{CBS+/-}$ mice (fig. 1a). This may be due to downregulation of one of the Hcy-metabolizing enzymes, CSE (fig. 1b), in addition to one copy of mutant CBS gene in $\mathrm{CBS}+/-$ mice. Hcy is one of the precursors of endogenous $\mathrm{H}_{2} \mathrm{~S}$ production. Therefore, an increased Hcy level and downregulation of its metabolizing enzyme will essentially decrease plasma $\mathrm{H}_{2} \mathrm{~S}$ level, a potent vasorelaxant gas. This will consequently result in hypertension, as we have observed in our study (fig. 2).

Our results also suggested that supplementation of $\mathrm{H}_{2} \mathrm{~S}$ resulted in normalization of blood pressure associated with HHcy (fig. 2). In addition to that, $\mathrm{NAD}(\mathrm{P}) \mathrm{H}$ oxidase ( $\mathrm{p} 47^{\text {phox }}$ subunit) was upregulated in WT $1 \mathrm{~K}$ and

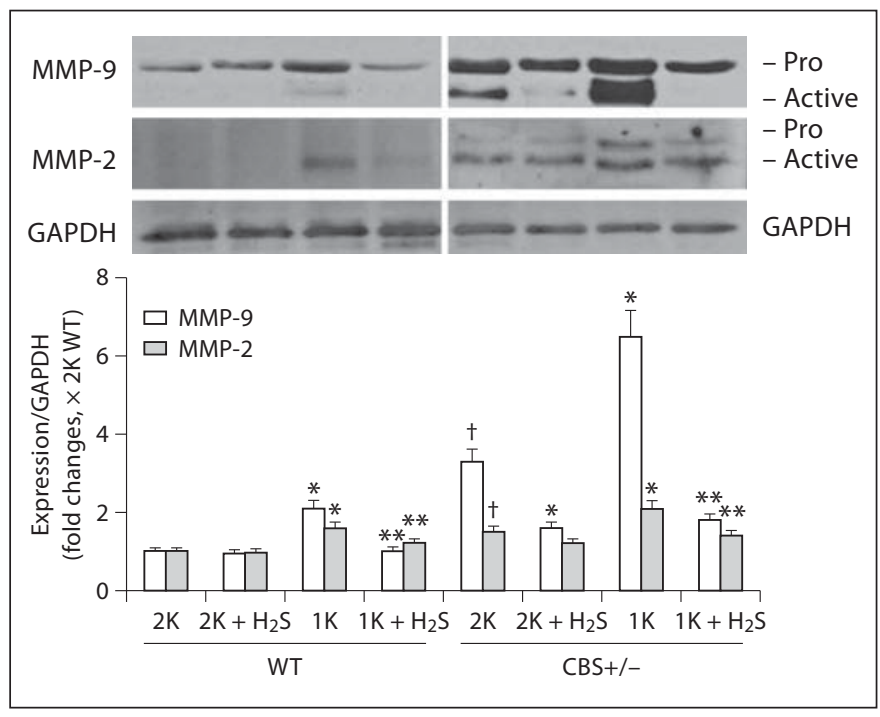

Fig. 6. $\mathrm{H}_{2} \mathrm{~S}$ attenuated MMP-2 and -9 expressions in the kidney. Western blot analyses were performed to measure MMP-2 and -9 in the kidney cortical tissue extract using anti-MMP-2 and antiMMP-9 antibodies, respectively. The bar diagram indicated densitometric analyses of expressed protein. Data represents the mean \pm SEM; $n=5-7$ per group. ${ }^{*} \mathrm{p}<0.05$ vs. respective $2 \mathrm{~K}$; ${ }^{* *}$ significant differences $(\mathrm{p}<0.05)$ vs. respective $1 \mathrm{~K} ;{ }^{\dagger} \mathrm{p}<0.05 \mathrm{vs}$. $2 \mathrm{~K} \mathrm{WT}$.

$\mathrm{CBS}+/-2 \mathrm{~K}$ and $1 \mathrm{~K}$ mice. The increased expression of this protein was normalized with $\mathrm{H}_{2} \mathrm{~S}$ supplementation, suggesting the anti-oxidant properties of $\mathrm{H}_{2} \mathrm{~S}$. Increased MMP-2 and -9, collagen protein expression, and histological collagen depositions were at least in part due to an increased oxidative-redox state. During HHcy, supplementation of $\mathrm{H}_{2} \mathrm{~S}$ normalized MMPs expressions and collagen accumulation in the glomerulus, suggesting the antifibrotic properties of $\mathrm{H}_{2} \mathrm{~S}$. Increased expressions of inflammatory molecules, ICAM-1 and VCAM-1, along with increased macrophage marker protein F4/80, were augmented with the decline of $\mathrm{H}_{2} \mathrm{~S}$ generation in the mouse-exhibited $\mathrm{HHcy}$, whereas $\mathrm{H}_{2} \mathrm{~S}$ supplementation prevented inflammation. Together, these results suggest that $\mathrm{HHcy}$ causes a decrease in endogenous $\mathrm{H}_{2} \mathrm{~S}$ generation, which eventually leads to hypertension, oxidative stress, matrix remodeling and chronic inflammation resulting in glomerulosclerosis and reduced glomerular function (GFR; fig. 3).

Renal dysfunction is recognized as a risk factor for increased cardiovascular morbidity and mortality [29], and chronic kidney disease is a graded cardiovascular risk factor that leads from renal impairment to end-stage re- 


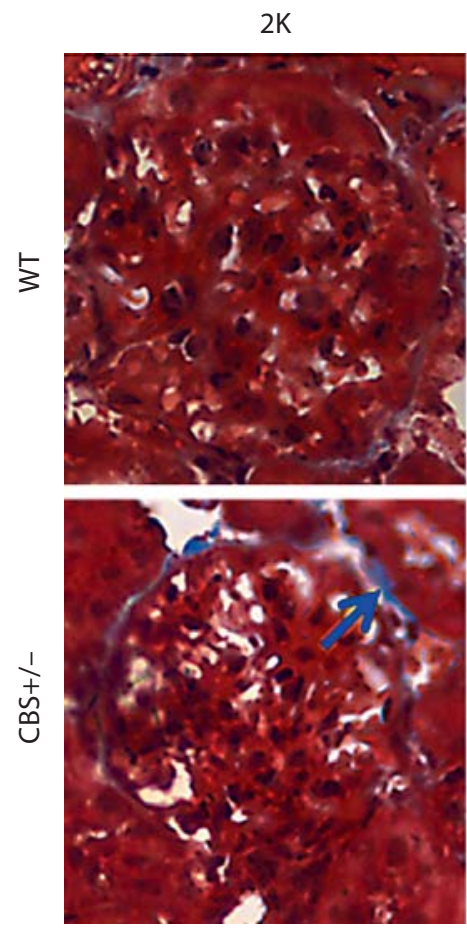

$2 \mathrm{~K}$
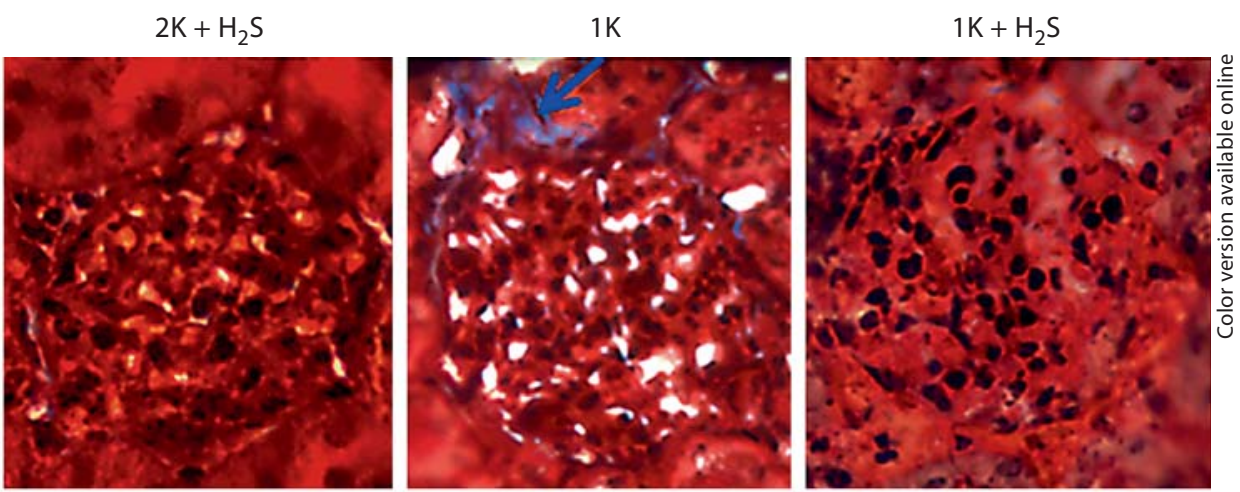

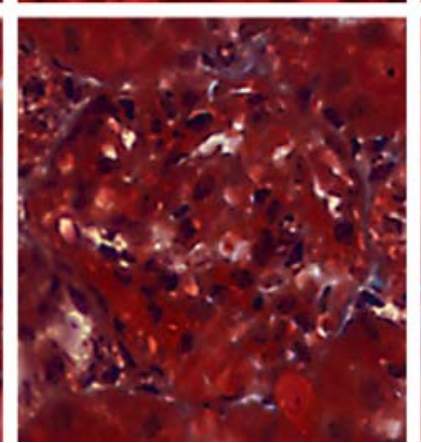

$2 \mathrm{~K}+\mathrm{H}_{2} \mathrm{~S}$

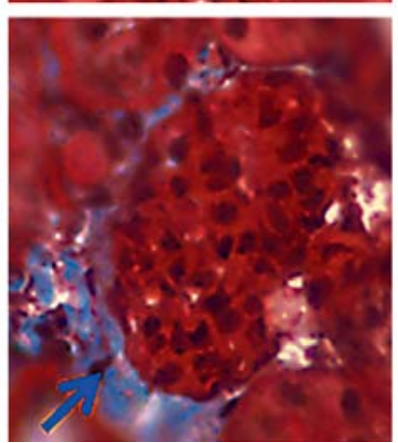

$1 \mathrm{~K}$

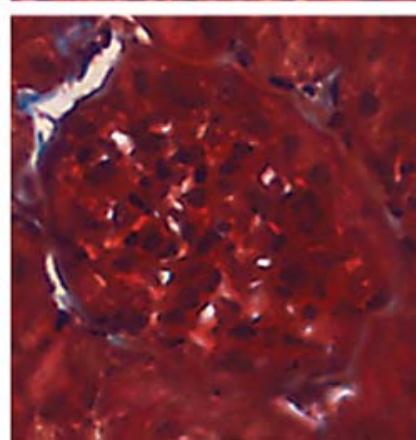

$1 \mathrm{~K}+\mathrm{H}_{2} \mathrm{~S}$
Fig. 7. Excessive collagen deposition in HHcy mice was ameliorated by $\mathrm{H}_{2} \mathrm{~S}$ supplementation. Histological kidney tissue sections were stained with Masson trichrome (collagen appears as blue, and indicated by arrows). $2 \mathrm{~K} \mathrm{CBS}+/-$ mice showed increased collagen deposition in the glomerular basement membrane, compared to $2 \mathrm{~K} \mathrm{WT}$. This collagen deposition in the glomerulus of $1 \mathrm{~K}$
$\mathrm{CBS}+/-$ mice was even higher than in $2 \mathrm{~K} \mathrm{CBS}+/-$ mice. When a separate group of $1 \mathrm{~K} \mathrm{CBS}+/$ - mice was supplemented with $\mathrm{H}_{2} \mathrm{~S}$ (NaHS, $30 \mu \mathrm{mol} / \mathrm{l}$ in drinking water) for 8 weeks postsurgery, the collagen appeared much less in the glomerulus. Notably, their $1 \mathrm{~K}$ WT littermates had very little collagen appearance and this disappeared with NaHS supplementation $(\mathrm{n}=7$ /group; $\times 200)$.

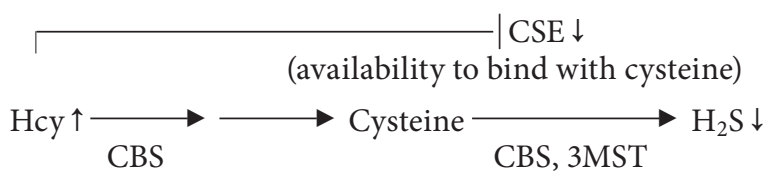

Previously we reported a decreased occurrence of plasma $\mathrm{H}_{2} \mathrm{~S}$ levels during HHcy [18]. In the present study we observed decreased renal production of $\mathrm{H}_{2} \mathrm{~S}$ in $\mathrm{HHcy}$ that resulted in hypertension (fig. 2). This result indicates that above substrate inhibition, a mechanism may be playing a role in producing $\mathrm{H}_{2} \mathrm{~S}$ during $\mathrm{HHcy}$. Furthermore, protein homocysteinylation is a major reaction in the presence of thiolactone and homocysteinylation led to protein damage. This manifested as multimerization and precipitation of extremely modified proteins [37]. Therefore, it may also be possible that Hcy at elevated levels homocysteinylates its metabolizing enzymes, including CSE, resulting in damage and precipitation of modified CSE. Therefore, we detected low expression of CSE protein in the renal tissue (fig. 1b). Although this was not within the 


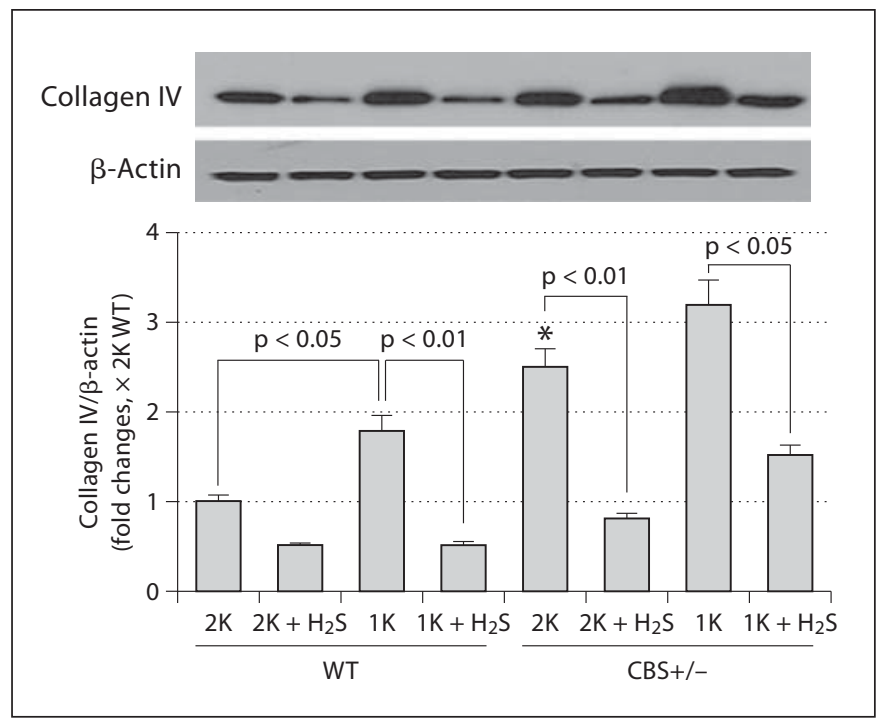

Fig. 8. $\mathrm{H}_{2} \mathrm{~S}$-attenuated collagen IV protein expression. Kidney cortex tissues were analyzed by Western blot using anticollagen IV antibody. While collagen expression was high in $1 \mathrm{~K} \mathrm{WT}$ and both $2 \mathrm{~K}$ and $1 \mathrm{~K} \mathrm{CBS}+/-$ mice, this increased expression was ameliorated with $\mathrm{H}_{2} \mathrm{~S}$ supplementation ( $\mathrm{NaHS}, 30 \mu \mathrm{mol} / \mathrm{l}$ ) for 8 weeks postsurgery. The bar diagram indicated densitometric analyses of the blots. Data represents the mean \pm SEM; $n=5-7 /$ group. ${ }^{*}$ Significant difference $(\mathrm{p}<0.05)$ compared to $2 \mathrm{~K}$ WT.

scope of the present study, this potential mechanism does require further experimentation.

Hcy contains a reactive sulfhydryl group and, like most thiols (RSH), can undergo oxidation to the disulfide (RSSR) at physiological $\mathrm{pH}$ in the presence of $\mathrm{O}_{2}$ [38]. A variety of reactive oxygen species can be produced upon Hcy oxidation, including superoxide $\left(\mathrm{O}_{2}^{\overline{1}}\right)$ and hydrogen peroxide $\left(\mathrm{H}_{2} \mathrm{O}_{2}\right)[39,40]$. Increasing evidence suggests that reactive oxygen species play an important role in the pathophysiology of glomerular dysfunction, interstitial fibrosis and glomerulosclerosis [5, 41]. Multiple enzymes contribute to exacerbating oxidative stress in different tissues and cells; however, studies have demonstrated that $\mathrm{NAD}(\mathrm{P}) \mathrm{H}$ oxidase is a major enzyme to produce superoxide $\left(\mathrm{O}_{2}^{\overline{2}}\right)$ in the kidney under physiological conditions [42]. Initially, $\mathrm{NAD}(\mathrm{P}) \mathrm{H}$ was characterized in neutrophils including membrane subunits $\mathrm{p} 22^{\text {phox }}$ and gp91 phox and cytoplasmic subunits $\mathrm{p} 47^{\text {phox }}, \mathrm{p} 40^{\text {phox }}, \mathrm{p} 67^{\text {phox }}$, and Rac GTPase $[43,44]$. It is generally accepted that in the event of $\mathrm{NAD}(\mathrm{P}) \mathrm{H}$ oxidase activation, the $\mathrm{p} 47^{\text {phox }}$ subunit plays a vital role $[45,46]$. Therefore, we tested the expression of p4 $7^{\text {phox }}$ both in in vivo and in vitro experimental conditions. Our results suggested that $\mathrm{p} 47^{\text {phox }}$ was upregulated in the animal groups exhibiting HHcy (fig. 4, and 5b) and

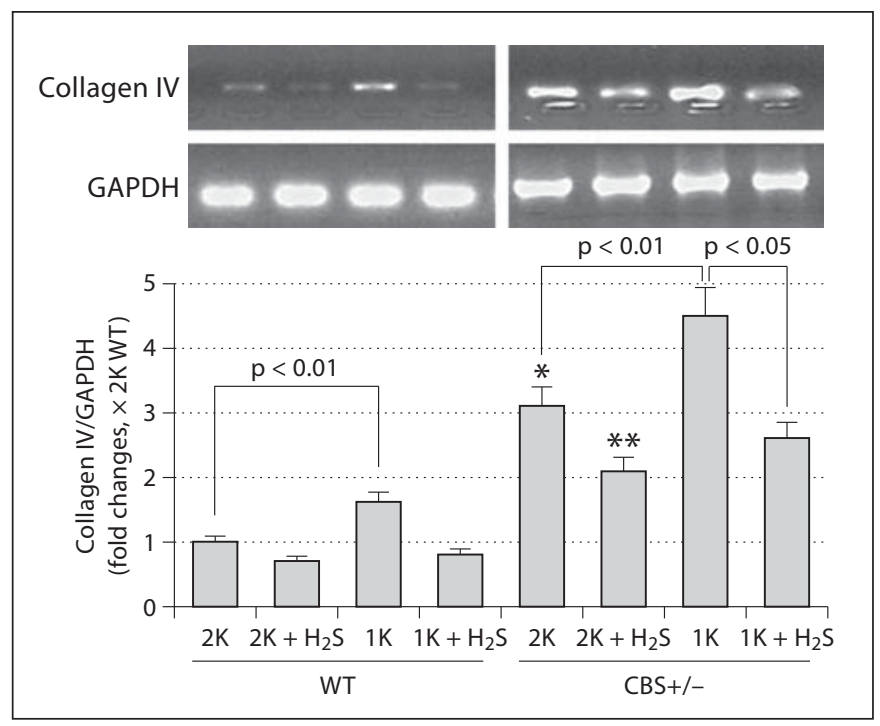

Fig. 9. Expression of collagen IV gene in the kidney cortical tissues. Renal cortical collagen protein was analyzed by Western blot. The bar diagram showed densitometric analyses of blots. Data represents the mean \pm SEM, $n=5-7 /$ group. ${ }^{*} \mathrm{p}<0.01 \mathrm{com}$ pared to WT $2 \mathrm{~K} ;{ }^{* *} \mathrm{p}<0.05$ compared to $\mathrm{CBS}+/-2 \mathrm{~K}$.

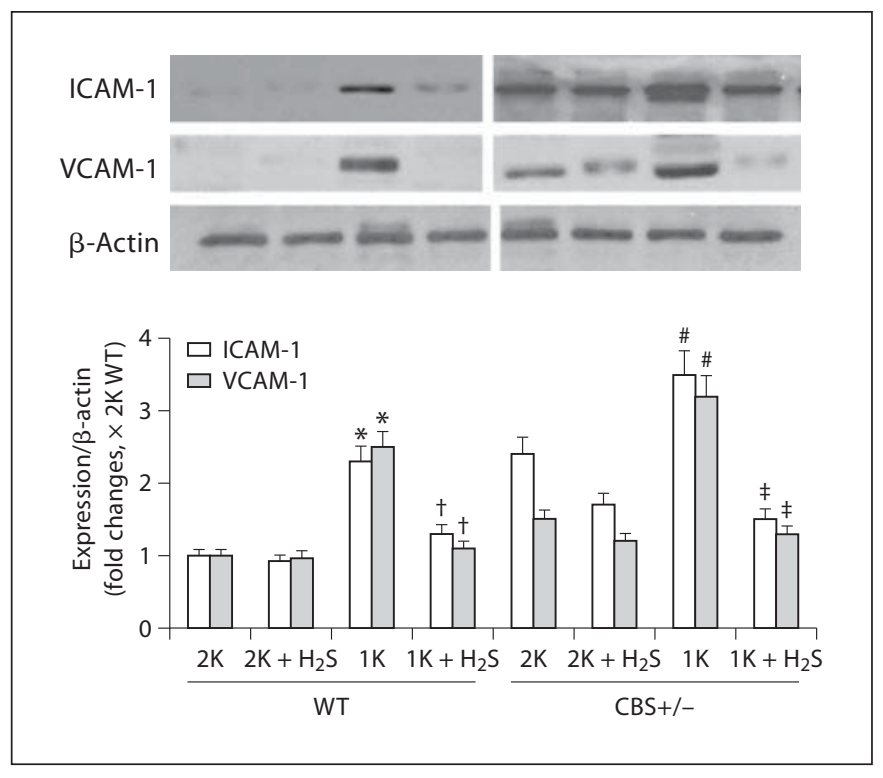

Fig. 10. Inflammatory molecule ICAM-1 and VCAM-1 were mitigated by $\mathrm{H}_{2} \mathrm{~S}$. Representative Western blot showed ICAM-1 and VCAM-1 expressions in the kidney cortex tissue in different experimental animal groups. The bar diagram indicated densitometric analyses of expressed protein in the respective blots. Data represents the mean \pm SEM, $\mathrm{n}=5-7 /$ group. ${ }^{*}$ Significant difference $(\mathrm{p}<0.01)$ compared to $2 \mathrm{~K}$ WT littermates; ${ }^{\dagger} \mathrm{p}<0.01$ vs. $1 \mathrm{~K}$ WT; ${ }^{\#} \mathrm{p}<0.01$ vs. $2 \mathrm{~K} \mathrm{CBS}+/-{ }^{\ddagger} \mathrm{p}<0.01$ vs. $1 \mathrm{~K} \mathrm{CBS}+/-$. 


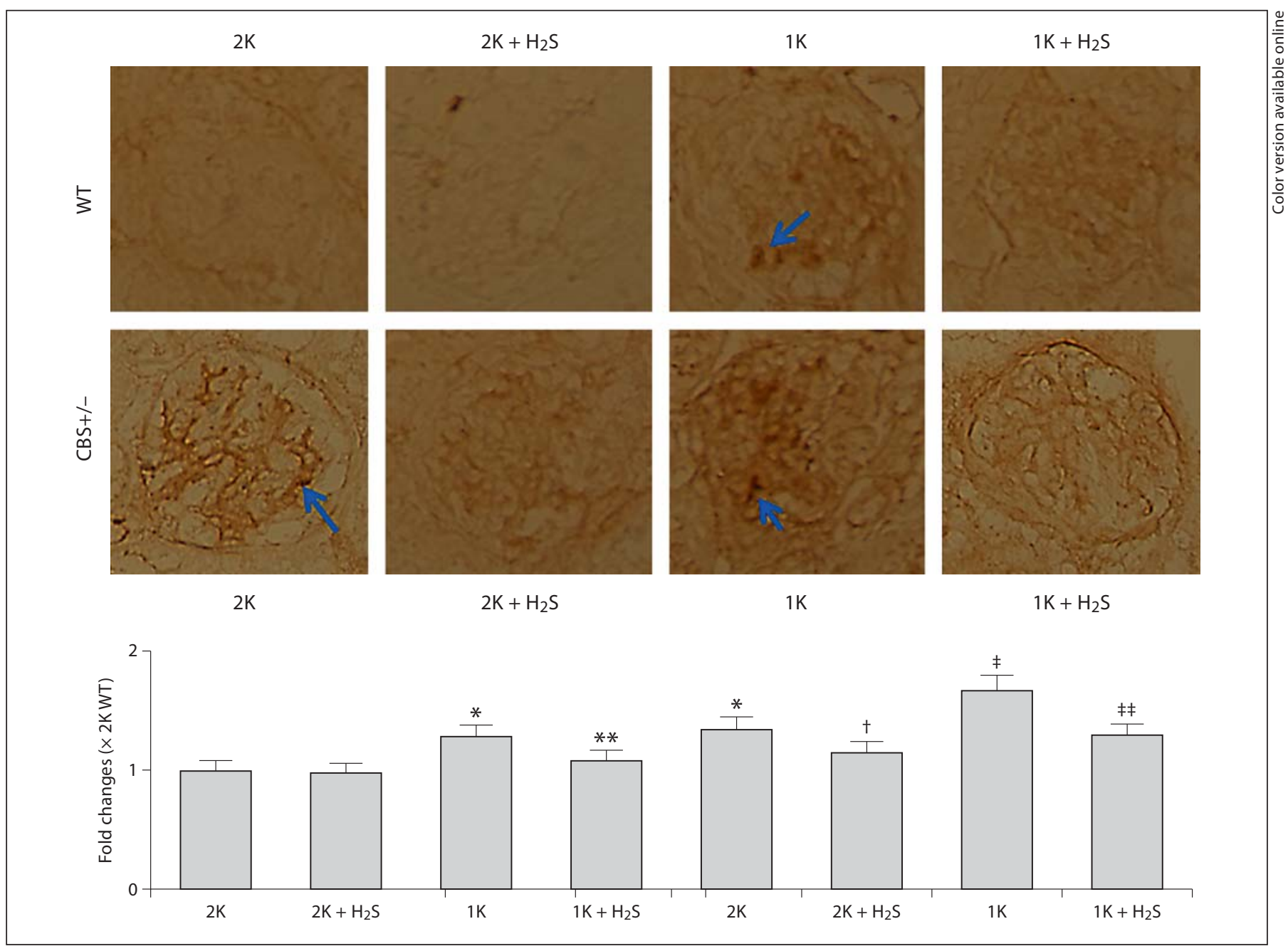

Fig. 11. Increased macrophage infiltration was mitigated by $\mathrm{H}_{2} \mathrm{~S}$. a Kidney tissue cryosections $(2-\mu \mathrm{m})$ were immunostained with macrophage F4/80 marker and visualized with $\operatorname{DAB}\left(3,3^{\prime}-\right.$ diaminobenzidine) staining. Increased brown staining, as indicated by arrows, in $1 \mathrm{~K} \mathrm{WT}, 2 \mathrm{~K} \mathrm{CBS}+/-$ and $1 \mathrm{~K} \mathrm{CBS}+/-$ mice indicated more macrophage infiltration in the glomerulus. In the similar groups, $\mathrm{H}_{2} \mathrm{~S}$ supplementation prevented this infiltration. Representative images ( $n=5 /$ group); data represent the mean \pm SEM. b Bar diagram showed intensity changes of DAB staining against $2 \mathrm{~K}$ WT glomerulus. ${ }^{*} \mathrm{p}<0.05$ vs. $2 \mathrm{~K} \mathrm{WT;}{ }^{* *} \mathrm{p}<0.05$ vs.

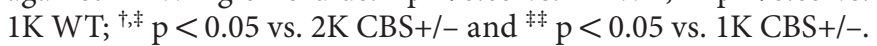

crepancy could be due to the difference in $\mathrm{H}_{2} \mathrm{~S}$ level between these two HHcy animal models. However, the discrepancy in $\mathrm{p}^{\text {phox }}$ levels between the present study and a previous report using the same type of cultured cells in vitro is puzzling [48]. The other report did not show a change in p47 phox levels by Hcy in cultured renal mesangial cells [48]. One possible reason may be due to Hcy stimulation for a prolonged period of time $(48 \mathrm{~h})$ in the present study versus the earlier report (16 h). However, the in vivo result of the present study suggests an upregulation of $\mathrm{p}^{47^{\text {hox }}}$ in the glomerulus which is diminished by $\mathrm{H}_{2} \mathrm{~S}$ treatment. 
MMP-2 and -9 are collagenases with more affinity for collagen IV and have been shown to have a renoprotective role by promoting turnover and, therefore, preventing matrix accumulation $[49,50]$. On the contrary, elevated expressions and activities of MMP-2 and -9 have been observed in the fibrotic renal cortex; therefore, they are documented as playing an important role in matrix accumulation associated with progressive renal scarring $(22,95)$. MMP-2 and -9 also degrade elastin more efficiently than other MMPs [51]. Because the turnover of collagen is faster than elastin, oxidatively modified collagen (glycated collagen) is deposited faster than elastin or any other ultra-structural matrix proteins [52].

We have previously reported that an increase of MMP2 and -9 activity was observed in the renal tissue from the animals exhibiting HHcy and lower levels of plasma $\mathrm{H}_{2} \mathrm{~S}$. In the present study we measured increased levels of MMP-2 and -9, collagen IV mRNA, and protein with the overall increase of deposition of collagen in the glomerulus of WT $1 \mathrm{~K}, \mathrm{CBS}+/-2 \mathrm{~K}$ and $\mathrm{CBS}+/-1 \mathrm{~K}$ mice. These results support our previous data [18] and suggest that MMP-2 and - 9 as well as collagen remodeling are associated with $\mathrm{HHcy}$-related chronic renal failure. Supplementation of $\mathrm{H}_{2} \mathrm{~S}$ can prevent these remodeling processes by regulating MMPs and collagen during HHcy-associated pathogenesis in the kidney (fig. 6-9).

Typically, glomerulosclerosis refers to a hardening of the glomerulus which frequently occurs due to collagen deposition. Glomerulosclerosis may be total where the entire glomerulus becomes hard and nonfunctional. Whereas partial glomerulosclerosis is often known as focal segmental glomerulosclerosis where part of the glomerulus becomes scar tissue. Early stages of glomerulosclerosis may produce little symptoms of scar tissue, which is collagen accumulation in our study (fig. 7); however, the most important warning sign is proteinuria. We have previously reported that HHcy animal groups developed proteinuria, whereas $\mathrm{H}_{2} \mathrm{~S}$ treatment partially prevented urinary protein loss [18]. Our present study further confirms our previous findings that the protein loss was primarily due to focal segmental glomerulosclerosis.

The excessive production of reactive oxygen species mediates renal fibrotic injury through activation of proinflammatory molecules. Recent studies of cytokines, chemokines and adhesion molecules have enhanced our understanding of molecular mechanisms of leukocyte trafficking and their activation in the inflammatory phase of various renovascular diseases [53]. Increased expressions of ICAM-1 and VCAM-1 have been shown as a potential mechanism facilitating lymphocytic infiltra- tion and organ dysfunction [54]. More importantly, experimental evidence has implicated sustained elevation of cell adhesion molecules, such as ICAM-1 and VCAM1 , in chronic inflammatory disorder, which leads to sclerosis [20]. HHcy has now been recognized as a pathophysiological stimulus of vascular endothelial dysfunction and has been shown to increase expression of ICAM-1 [19] and VCAM-1 [19, 21] in experimental models. However, an Hcy-induced inflammatory reaction in the glomerulus during renal diseases was clearly not defined. The present study further supports our previous findings [18] and demonstrates that macrophage infiltration and increased expression of ICAM-1 and VCAM-1 (fig. 10, 11) are associated with HHcy. These events are partially, if not completely, preventable by $\mathrm{H}_{2} \mathrm{~S}$ treatment, suggesting the possible protective role of $\mathrm{H}_{2} \mathrm{~S}$ through its antioxidant properties during HHcy-associated renal inflammation and remodeling. However, the relationship between oxidant stress and inflammation, i.e. which is the upstream effector in HHcy, was not adequately addressed in the present study because inflammation has also been shown to cause oxidant stress. Blocking either pathway may clarify this question. Nevertheless, the present results reveal that oxidative stress is one of the, if not only, upstream effectors of HHcy.

In summary, we demonstrated that increased oxidative stress in HHcy-associated renal cortical tissue is due to, in part, reduced renal $\mathrm{H}_{2} \mathrm{~S}$ production and upregulation of the $47^{\text {phox }}$ subunit of $\mathrm{NAD}(\mathrm{P}) \mathrm{H}$ oxidase. These lead to MMPs and collagen remodeling in the glomerulus along with the increase in inflammatory response resulting in glomerulosclerosis, reduced glomerular function and hypertension. These structural and functional changes are associated with HHcy and are preventable by $\mathrm{H}_{2} \mathrm{~S}$ supplementation.

\section{Acknowledgement}

This study was supported, in part, by NIH grants HL-71010, HL-74185, HL-88012 and NS-51568.

References

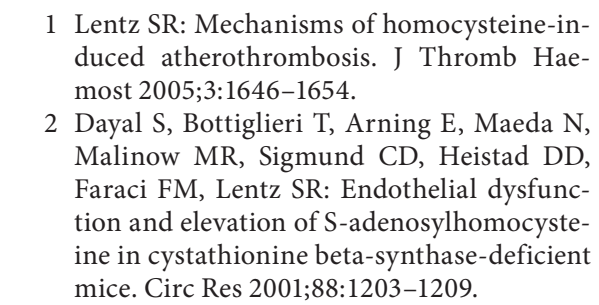

Am J Nephrol 2010;31:442-455 
-3 Diez N, Perez R, Hurtado V, Santidrian S: Hyperhomocysteinaemia induced by dietary folate restriction causes kidney oxidative stress in rats. Br J Nutr 2005;94:204-210.

4 Zhang F, Siow YL, O K: Hyperhomocysteinemia activates NF-kappaB and inducible nitric oxide synthase in the kidney. Kidney Int 2004;65:1327-1338.

5 Yi F, Li PL: Mechanisms of homocysteineinduced glomerular injury and sclerosis. Am J Nephrol 2008;28:254-264.

6 Shibuya N, Mikami Y, Kimura Y, Nagahara N, Kimura H: Vascular endothelium expresses 3-mercaptopyruvate sulfurtransferase and produces hydrogen sulfide. J Biochem 2009; 146:623-626.

7 Shibuya N, Tanaka M, Yoshida M, Ogasawara $\mathrm{Y}$, Togawa $\mathrm{T}$, Ishii $\mathrm{K}$, Kimura $\mathrm{H}$ : 3-mercaptopyruvate sulfurtransferase produces hydrogen sulfide and bound sulfane sulfur in the brain. Antioxid Redox Signal 2009;11:703-714.

-8 Geng B, Yang J, Qi Y, Zhao J, Pang Y, Du J, Tang C: $\mathrm{H}_{2} \mathrm{~S}$ generated by heart in rat and its effects on cardiac function. Biochem Biophys Res Commun 2004;313:362-368.

$\checkmark 9$ Swaroop M, Bradley K, Ohura T, Tahara T, Roper MD, Rosenberg LE, Kraus JP: Rat cystathionine beta-synthase. Gene organization and alternative splicing. J Biol Chem 1992; 267:11455-11461.

10 Lowicka E, Beltowski J: Hydrogen sulfide $\left(\mathrm{H}_{2} \mathrm{~S}\right)$ - the third gas of interest for pharmacologists. Pharmacol Rep 2007;59:4-24.

-11 Kimura Y, Dargusch R, Schubert D, Kimura $\mathrm{H}$ : Hydrogen sulfide protects HT22 neuronal cells from oxidative stress. Antioxid Redox Signal 2006;8:661-670.

-12 Yonezawa D, Sekiguchi F, Miyamoto M, Taniguchi E, Honjo M, Masuko T, Nishikawa $\mathrm{H}$, Kawabata A: A protective role of hydrogen sulfide against oxidative stress in rat gastric mucosal epithelium. Toxicology 2007;241:11-18.

13 Wei HL, Zhang CY, Jin HF, Tang CS, Du JB: Hydrogen sulfide regulates lung tissue-oxidized glutathione and total antioxidant capacity in hypoxic pulmonary hypertensive rats. Acta Pharmacol Sin 2008;29:670-679.

14 Fu Z, Liu X, Geng B, Fang L, Tang C: Hydrogen sulfide protects rat lung from ischemiareperfusion injury. Life Sci 2008;82:11961202.

- 15 Zanardo RC, Brancaleone V, Distrutti E, Fiorucci S, Cirino G, Wallace JL: Hydrogen sulfide is an endogenous modulator of leukocyte-mediated inflammation. FASEB J 2006; 20:2118-2120.

>16 Hu LF, Wong PT, Moore PK, Bian JS: Hydrogen sulfide attenuates lipopolysaccharideinduced inflammation by inhibition of p38 mitogen-activated protein kinase in microglia. J Neurochem 2007;100:1121-1128.
17 Rao VH, Lees GE, Kashtan CE, Nemori R, Singh RK, Meehan DT, Rodgers K, Berridge $\mathrm{BR}$, Bhattacharya G, Cosgrove D: Increased expression of MMP-2, MMP-9 (type IV collagenases/gelatinases), and MT1-MMP in canine X-linked Alport syndrome (XLAS). Kidney Int 2003;63:1736-1748.

-18 Sen U, Basu P, Abe OA, Givvimani S, Tyagi N, Metreveli N, Shah KS, Passmore JC, Tyagi SC: Hydrogen sulfide ameliorates hyperhomocysteinemia-associated chronic renal failure. Am J Physiol Renal Physiol 2009; 297:F410-F419.

-19 Sen U, Tyagi N, Kumar M, Moshal KS, Rodriguez WE, Tyagi SC: Cystathionine-betasynthase gene transfer and 3-deazaadenosine ameliorate inflammatory response in endothelial cells. Am J Physiol Cell Physiol 2007; 293:C1779-C1787.

-20 Silverman MD, Tumuluri RJ, Davis M, Lopez G, Rosenbaum JT, Lelkes PI: Homocysteine upregulates vascular cell adhesion molecule-1 expression in cultured human aortic endothelial cells and enhances monocyte adhesion. Arterioscler Thromb Vasc Biol 2002; 22:587-592.

-21 Hofmann MA, Lalla E, Lu Y, Gleason MR, Wolf BM, Tanji N, Ferran LJ Jr, Kohl B, Rao V, Kisiel W, Stern DM, Schmidt AM: Hyperhomocysteinemia enhances vascular inflammation and accelerates atherosclerosis in a murine model. J Clin Invest 2001;107: 675-683.

-22 Kikuchi Y, Imakiire T, Yamada M, Saigusa T, Hyodo T, Hyodo N, Suzuki S, Miura S: Mizoribine reduces renal injury and macrophage infiltration in non-insulin-dependent diabetic rats. Nephrol Dial Transplant 2005; 20:1573-1581.

-23 Richardson CJ, Magee EA, Cummings JH: A new method for the determination of sulphide in gastrointestinal contents and whole blood by microdistillation and ion chromatography. Clin Chim Acta 2000;293:115125.

24 Li L, Bhatia M, Zhu YZ, Zhu YC, Ramnath RD, Wang ZJ, Anuar FB, Whiteman M, Salto-Tellez M, Moore PK: Hydrogen sulfide is a novel mediator of lipopolysaccharide-induced inflammation in the mouse. FASEB J 2005;19:1196-1198.

-25 Maezawa Y, Yokote K, Sonezaki K, Fujimoto M, Kobayashi K, Kawamura H, Tokuyama T, Takemoto M, Ueda S, Kuwaki T, Mori S, Wahren J, Saito Y: Influence of C-peptide on early glomerular changes in diabetic mice. Diabetes Metab Res Rev 2006;22:313-322.

-26 Lorenz JN, Gruenstein E: A simple, nonradioactive method for evaluating singlenephron filtration rate using FITC-inulin. Am J Physiol 1999;276:F172-F177.

-27 Rodriguez WE, Tyagi N, Joshua IG, Passmore JC, Fleming JT, Falcone JC, Tyagi SC: Pioglitazone mitigates renal glomerular vascular changes in high-fat, high-calorie-induced type 2 diabetes mellitus. Am J Physiol Renal Physiol 2006;291:F694-F701.
28 Li N, Chen YF, Zou AP: Implications of hyperhomocysteinemia in glomerular sclerosis in hypertension. Hypertension 2002;39: 443-448.

29 Rodionov RN, Lentz SR: The homocysteine paradox. Arterioscler Thromb Vasc Biol 2008;28:1031-1033.

30 Schiffrin EL, Lipman ML, Mann JF: Chronic kidney disease: effects on the cardiovascular system. Circulation 2007;116:85-97.

-31 Friedman AN, Bostom AG, Selhub J, Levey AS, Rosenberg IH: The kidney and homocysteine metabolism. J Am Soc Nephrol 2001; 12:2181-2189.

32 Yang G, Wu L, Jiang B, Yang W, Qi J, Cao K, Meng Q, Mustafa AK, Mu W, Zhang S, Snyder $\mathrm{SH}$, Wang $\mathrm{R}$ : $\mathrm{H}_{2} \mathrm{~S}$ as a physiologic vasorelaxant: hypertension in mice with deletion of cystathionine gamma-lyase. Science 2008; 322:587-590.

33 Fang L, Li H, Tang C, Geng B, Qi Y, Liu X: Hydrogen sulfide attenuates the pathogenesis of pulmonary fibrosis induced by bleomycin in rats. Can J Physiol Pharmacol 2009;87: 531-538.

34 Mishra PK, Tyagi N, Sen U, Givvimani S, Tyagi SC: $\mathrm{H}_{2} \mathrm{~S}$ ameliorates oxidative and proteolytic stresses and protects the heart against adverse remodeling in chronic heart failure. Am J Physiol Heart Circ Physiol 2010;298:H451-H456.

35 Stabler SP, Steegborn C, Wahl MC, Oliveriusova J, Kraus JP, Allen $\mathrm{RH}$, Wagner C, Mudd SH: Elevated plasma total homocysteine in severe methionine adenosyltransferase I/III deficiency. Metabolism 2002;51: 981-988.

>36 Chang L, Geng B, Yu F, Zhao J, Jiang H, Du J, Tang C: Hydrogen sulfide inhibits myocardial injury induced by homocysteine in rats. Amino Acids 2008;34:573-585.

37 Jakubowski H: Protein homocysteinylation: possible mechanism underlying pathological consequences of elevated homocysteine levels. FASEB J 1999;13:2277-2283.

>38 Jacobsen DW: Hyperhomocysteinemia and oxidative stress: Time for a reality check? Arterioscler Thromb Vasc Biol 2000;20:11821184.

39 Jacobsen DW, Troxell LS, Brown KL: Catalysis of thiol oxidation by cobalamins and cobinamides - reaction-products and kinetics. Biochemistry 1984;23:2017-2025.

40 Misra HP: Generation of superoxide free radical during the autoxidation of thiols. J Biol Chem 1974;249:2151-2155.

-41 Brezniceanu ML, Liu F, Wei CC, Chenier I, Godin N, Zhang SL, Filep JG, Ingelfinger JR, Chan JS: Attenuation of interstitial fibrosis and tubular apoptosis in $\mathrm{db} / \mathrm{db}$ transgenic mice overexpressing catalase in renal proximal tubular cells. Diabetes 2008;57:451-459. 
\$2 Griendling KK, Sorescu D, Lassegue B, Ushio-Fukai M: Modulation of protein kinase activity and gene expression by reactive oxygen species and their role in vascular physiology and pathophysiology. Arterioscler Thromb Vasc Biol 2000;20:2175-2183.

43 Brandes RP, Kreuzer J: Vascular NADPH oxidases: molecular mechanisms of activation. Cardiovasc Res 2005;65:16-27.

-44 Takeya R, Ueno N, Kami K, Taura M, Kohjima M, Izaki T, Nunoi $H$, Sumimoto $H$ : Novel human homologues of $\mathrm{p} 47^{\mathrm{phox}}$ and p67 phox participate in activation of superoxide-producing NADPH oxidases. J Biol Chem 2003;278:25234-25246.

45 Madamanchi NR, Vendrov A, Runge MS: Oxidative stress and vascular disease. Arterioscler Thromb Vasc Biol 2005;25:29-38.

-46 Sellmayer A, Obermeier H, Danesch U, Aepfelbacher M, Weber PC: Arachidonic acid increases activation of NADPH oxidase in monocytic U937 cells by accelerated translocation of p47-phox and co-stimulation of protein kinase C. Cell Signal 1996;8:397402.
7 Ungvari Z, Csiszar A, Edwards JG, Kaminski PM, Wolin MS, Kaley G, Koller A: Increased superoxide production in coronary arteries in hyperhomocysteinemia: role of tumor necrosis factor-alpha, NAD $(\mathrm{P}) \mathrm{H}$ oxidase, and inducible nitric oxide synthase. Arterioscler Thromb Vasc Biol 2003;23:418424.

-48 Yi F, Zhang AY, Janscha JL, Li PL, Zou AP: Homocysteine activates NADH/NADPH oxidase through ceramide-stimulated Rac GTPase activity in rat mesangial cells. Kidney Int 2004;66:1977-1987.

49 Endo T, Nakabayashi K, Sekiuchi M, Kuroda T, Soejima A, Yamada A: Matrix metalloproteinase-2, matrix metalloproteinase-9, and tissue inhibitor of metalloproteinase-1 in the peripheral blood of patients with various glomerular diseases and their implication in pathogenetic lesions: study based on an en zyme-linked assay and immunohistochemical staining. Clin Exp Nephrol 2006;10:253261.
50 Rysz J, Banach M, Stolarek RA, Pasnik J, Cialkowska-Rysz A, Koktysz R, Piechota M, Baj Z: Serum matrix metalloproteinases MMP-2 and MMP-9 and metalloproteinase tissue inhibitors TIMP-1 and TIMP-2 in diabetic nephropathy. J Nephrol 2007;20:444452 .

51 Senior RM, Griffin GL, Fliszar CJ, Shapiro SD, Goldberg GI, Welgus HG: Human 92and 72-kilodalton type IV collagenases are elastases. J Biol Chem 1991;266:7870-7875.

52 Camp TM, Tyagi SC, Senior RM, Hayden MR: Gelatinase B(MMP-9) an apoptotic factor in diabetic transgenic mice. Diabetologia 2003;46:1438-1445.

53 Bonventre JV: Pathophysiology of acute kidney injury: roles of potential inhibitors of inflammation. Contrib Nephrol 2007;156:3946.

54 Anderson JA, Lentsch AB, Hadjiminas DJ, Miller FN, Martin AW, Nakagawa K, Edwards MJ: The role of cytokines, adhesion molecules, and chemokines in interleukin-2induced lymphocytic infiltration in C57BL/6 mice. J Clin Invest 1996;97:1952-1959. 